\title{
Mutant selection window of clarithromycin for clinical isolates of Helicobacter pylori
}

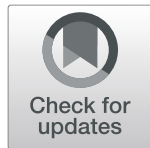

Zi-Han Feng ${ }^{1 \dagger}$, Ling Fan ${ }^{2 \dagger}$, Jing Yang ${ }^{2}$, Xing-Yue Huo ${ }^{2}$, Yan Guo ${ }^{2}$, Yi Zhang ${ }^{2}$ and Chun-Hui Lan ${ }^{2 *}$ (D)

\begin{abstract}
Background: Clarithromycin-resistance is becoming a global health concern in the treatment of Helicobacter pylori (H. pylori). The mutant prevention concentration (MPC) represent the propensities of antimicrobial agents to select resistant mutants. The concentration range between the minimum inhibitory concentration (MIC) and the MPC is defined as mutant selection window (MSW). In this study, we aimed to determine the cause of increasing clarithromycin resistance by investigating the MSW for clinical isolates of H. pylori.

Results: A retrospective subgroup, which included 68 clarithromycin-sensitive H. pylori strains, was selected from a double-blind trial. The MICs and MPCs were determined using agar plate assays. Genotypic tests were performed using Sanger sequencing. All isolates were wild-type, and 33.82\% (23/68) had a $0.016 \mathrm{mg} / \mathrm{L} \mathrm{MIC,45.59 \% (31/68)} \mathrm{had}$ a $0.031 \mathrm{mg} / \mathrm{L} \mathrm{MIC,} 16.18 \%(11 / 68)$ had a $0.062 \leq \mathrm{MIC} \leq 0.125 \mathrm{mg} / \mathrm{L}$, and $4.41 \%(3 / 68)$ had a $0.25 \mathrm{mg} / \mathrm{L} \mathrm{MIC}$. The $\mathrm{MPC}_{50 / 90}$ (mg/L) of the isolates were: $0.062 / 0.125,0.125 / 0.5,0.25 / 0.25$ and $1 / 2$, respectively. The MPCs showed a moderate correlation with the MICs $\left(r_{s}=0.65, P<0.0001\right)$. Using published data and MPC90, we calculated the time inside the MSW (TMSW) for low- and high-dose (200 or $500 \mathrm{mg}$ bid) clarithromycin that were 6 and $0 \mathrm{~h}, 24$ and $4 \mathrm{~h}$, 15 and $2 \mathrm{~h}, 5$ and $17 \mathrm{~h}$ for the strains with MICs (mg/L) of 0.016, 0.031, 0.062-0.125, and 0.25, respectively.

Conclusions: This study showed that in the clarithromycin-sensitive clinical isolates of H. pylori, low-dose clarithromycin may lead to decreased drug sensitivity or even clarithromycin resistance; strains with a $0.25 \mathrm{mg} / \mathrm{L}$ MIC display a high risk of treatment failure.
\end{abstract}

Keywords: Helicobacter pylori, Clarithromycin, MPC, MSW, Antibiotic resistance

\section{Background}

Clarithromycin is the most powerful antimicrobial agent used in the treatment of Helicobacter pylori (H. pylori) infection [1], yet it is recognized as a major cause of peptic ulcers [2]. Treatment of H. pylori with clarithromycin alone is far from satisfactory [3], while the performance of clarithromycin is markedly improved when combined with other agents, particularly acid suppressive agents [4]. Several clarithromycin-based triple therapies including clarithromycin, amoxicillin, and ranitidine were previously found to be highly effective $[5,6]$. Now, clarithromycin-containing bismuth quadruple therapies are recommended by many international guidelines in the treatment of $H$. pylori

\footnotetext{
* Correspondence: lanchunhui@tmmu.edu.cn

${ }^{\dagger}$ Zi-Han Feng and Ling Fan contributed equally to this work.

2Department of Gastroenterology, Daping Hospital, Army Medical University,

10 Changjiang Branch Road, Chongqing 400042, China

Full list of author information is available at the end of the article
}

infection [7-11]. Therefore, clarithromycin continues to play an important role in $H$. pylori treatment.

Recently, clarithromycin resistance has been steadily increasing worldwide. In addition, resistance to clarithromycin has been ranked as a high priority pathogen by the World Health Organization [12]. The eradication rate has been severely reduced with clarithromycin-containing bismuth quadruple therapies [7]. While it is known that a history of prior clarithromycin use can influence the failure rate of standard triple therapies in patients [13], the mechanisms by which it affects the MICs and the reasoning for the skyrocketing increase in resistance to clarithromycin is unknown [1].

The mutant prevention concentration (MPC) represents the lowest drug concentration that prevents firststep mutant subpopulation growth in a large bacterial population, usually more than $10^{10}$ colony forming unit (CFU)/mL bacteria [14]. The mutant selection window (MSW) is the range of antibiotic concentrations above

(C) The Author(s). 2019 Open Access This article is distributed under the terms of the Creative Commons Attribution 4.0 International License (http://creativecommons.org/licenses/by/4.0/), which permits unrestricted use, distribution, and 
the minimum inhibitory concentration (MIC) and below the MPC. If the maximum serum concentration is within the MSW, the growth of susceptible bacteria is suppressed, and the non-susceptible mutant variants are selectively enriched, resulting in eradication failure [15]. The MPC theory has been used to compare drug susceptibility and to investigate the relationships between pharmacokinetic and pharmacodynamic (PKPD) values and resistance in various of bacteria, such as Mannheimia haemolytica [16], Escherichia coli [17], Staphylococcus aureus [18], Salmonella enterica [19], and Pseudomonas aeruginosa [20]. As of now, there are no published reports on the MPC of clarithromycin for clinical isolates of $H$. pylori.

In this study, we aim to investigate the MPC of clarithromycin-sensitive clinical isolates of $H$. pylori. To investigate the reasoning for the increased rates of clarithromycin resistance, the MPC was combined with the PKPD values for low- and high-dose (200 or $500 \mathrm{mg}$ bid) clarithromycin to calculate changes in the MICs during the treatment of respiratory and $H$. pylori infections.

\section{Results}

Clinical characteristics of patients are provided in Table 1. Genotypic tests showed that all isolates were wild-type. $33.82 \%(23 / 68)$ had a $0.016 \mathrm{mg} / \mathrm{L} \mathrm{MIC}$, $45.59 \%(31 / 68)$ had a $0.031 \mathrm{mg} / \mathrm{L}$ MIC, $16.18 \%(11 / 68)$ had a $0.062 \leq \mathrm{MIC} \leq 0.125 \mathrm{mg} / \mathrm{L}, 4.41 \%(3 / 68)$ had a 0.25 $\mathrm{mg} / \mathrm{L}$ MIC. There were no significant differences between the eradication rate of strains with different MICs.

The $\mathrm{MPC}_{50}$ values for clarithromycin in the strains with different MICs were $0.062,0.125,0.25$ and $1 \mathrm{mg} / \mathrm{L}$, respectively. The $\mathrm{MPC}_{90}$ values were $0.125,0.5,0.25$ and $2 \mathrm{mg} / \mathrm{L}$, respectively (Table 2). The MPCs showed a moderate correlation with the MICs $\left(r_{s}=0.65, P<0.0001\right)$. The $\mathrm{MIC}_{90}$ and $\mathrm{MPC}_{90}$ represented the boundaries of the MSW [21]. The window sizes were $16(0.016,0.125), 16$ $(0.031,0.5), 4(0.062,0.25)$, and $8(0.25,2.0)$ for the strains with the MICs $(\mathrm{mg} / \mathrm{L})$ of $0.016,0.031,0.062-0.125$, and 0.25 , respectively. Strains with smaller MICs had bigger MSW boundaries.

The pharmacodynamic indices were determined by combining the MPC and MIC values with the pharmacokinetic parameters, such as area under curve over $24 \mathrm{~h}$ $\left(\mathrm{AUC}_{24}\right)$ and serum maximum concentration $\left(\mathrm{C}_{\max }\right)$, as shown in Table 3. The $\mathrm{C}_{\max } / \mathrm{MPC}_{90}, \mathrm{AUC}_{24} / \mathrm{MPC}_{90}$ and time inside the MSW ( $\left.\mathrm{T}_{\mathrm{MSW}}\right)$ were calculated for two dosages in the treatment of $H$. pylori infection $(500 \mathrm{mg}$ bid), and respiratory infections (200 mg bid).

When the dosage of clarithromycin is $200 \mathrm{mg}$ bid, the $\mathrm{C}_{\max } / \mathrm{MPC}_{90}$ is 2.88 for strains with the MICs of 0.016 $\mathrm{mg} / \mathrm{L} ; 0.72$ for strains with the MICs of $0.031 \mathrm{mg} / \mathrm{L} ; 1.44$ for strains with the MICs ranging from 0.062 to $0.125 \mathrm{mg} /$ $\mathrm{L}$; and 0.18 for strains with the MICs of $0.25 \mathrm{mg} / \mathrm{L}$. When the dosage of clarithromycin is $500 \mathrm{mg}$ bid, the $\mathrm{C}_{\max } /$ $\mathrm{MPC}_{90}$ is 22.80 for strains with the MICs of $0.016 \mathrm{mg} / \mathrm{L}$; 5.70 for strains with the MICs of $0.031 \mathrm{mg} / \mathrm{L} ; 11.40$ for strains with the MICs ranging from 0.062 to $0.125 \mathrm{mg} / \mathrm{L}$; and 1.43 for strains with the MICs of $0.25 \mathrm{mg} / \mathrm{L}$.

When the dosage of clarithromycin is $200 \mathrm{mg}$ bid, the $\mathrm{AUC}_{24} / \mathrm{MPC}$ is 33.60 for strains with the MICs of 0.016 $\mathrm{mg} / \mathrm{L} ; 8.4$ for strains with the MICs of $0.031 \mathrm{mg} / \mathrm{L} ; 16.80$ for strains with the MICs ranging from 0.062 to 0.125 $\mathrm{mg} / \mathrm{L} ; 2.10$ for strains with the MICs of $0.25 \mathrm{mg} / \mathrm{L}$. When the dosage of clarithromycin is $500 \mathrm{mg}$ bid, the $\mathrm{AUC}_{24} / \mathrm{MPC}$ is 333.76 for strains with the MICs of 0.016 $\mathrm{mg} / \mathrm{L} ; 83.44$ for strains with the MICs of $0.031 \mathrm{mg} / \mathrm{L}$; 166.88 for strains with the MICs ranging from 0.062 to $0.125 \mathrm{mg} / \mathrm{L} ; 20.86$ for strains with the MICs of $0.25 \mathrm{mg} / \mathrm{L}$.

When the dosage of clarithromycin is $200 \mathrm{mg}$ bid, the $\mathrm{T}_{\mathrm{MSW}}$ (h) is 6 for strains with the MICs of $0.016 \mathrm{mg} / \mathrm{L}$; 24 for strains with the MICs of $0.031 \mathrm{mg} / \mathrm{L} ; 15$ for strains with the MICs ranging from 0.062 to $0.125 \mathrm{mg} / \mathrm{L}$; and 5 for strains with the MICs of $0.25 \mathrm{mg} / \mathrm{L}$. The $\mathrm{T}_{\mathrm{MSW}}$ values indicate that non-susceptible mutant subpopulations are more likely to be selectively enriched with the low-dose clarithromycin. As a result, the MICs increase with low-

Table 1 Baseline demographics and clinical and characteristics of patients with different MIC values

\begin{tabular}{|c|c|c|c|c|c|c|}
\hline \multirow[b]{2}{*}{ Characteristics } & \multicolumn{4}{|c|}{ MIC distribution data } & \multirow[t]{2}{*}{ Total } & \multirow[t]{2}{*}{$P$-value } \\
\hline & $\leq 0.016$ & 0.031 & $0.062-0.125$ & 0.25 & & \\
\hline Gender (male/female) & $11 / 12$ & $14 / 17$ & $6 / 5$ & $2 / 1$ & $33 / 35$ & 0.9185 \\
\hline Age, mean $\pm S D$ (years) & $45 \pm 11.43$ & $41 \pm 10.84$ & $\begin{array}{l}42 \pm \\
10.80\end{array}$ & $38 \pm 12.70$ & $42 \pm 11.06$ & 0.5475 \\
\hline Cigarette smoking (yes/no) & $6 / 17$ & $8 / 23$ & $2 / 9$ & $2 / 1$ & $18 / 50$ & 0.4952 \\
\hline Alcohol drinking (yes/no) & $9 / 14$ & $13 / 18$ & $6 / 5$ & $0 / 3$ & $28 / 40$ & 0.4737 \\
\hline Endoscopic findings (PUD/NUD) & $4 / 19$ & $8 / 23$ & $5 / 6$ & $0 / 3$ & $17 / 51$ & 0.2890 \\
\hline Eradication rate & $100 \%(23 / 23)$ & $93.55 \%(29 / 31)$ & $90.91 \%(10 / 11)$ & $100 \%(3 / 3)$ & $95.59 \%(65 / 68)$ & 0.4736 \\
\hline BQT & $100 \%(17 / 17)$ & $91.67 \%(22 / 24)$ & $87.5 \%(7 / 8)$ & $100 \%(3 / 3)$ & $94.23 \%(49 / 52)$ & 0.4923 \\
\hline Others & $100 \%(6 / 6)$ & $100 \%(7 / 7)$ & $100 \%(3 / 3)$ & None & $100 \%(16 / 16)$ & 1.0000 \\
\hline
\end{tabular}

SD standard deviation, PUD peptic ulcer disease, NUD non-ulcer dyspepsia, BQT clarithromycin-containing bismuth quadruple therapy. Concentrations are in mg/L 
Table 2 MIC/MPC distribution for clarithromycin with clinical isolates of H. pylori $(n=68)$

\begin{tabular}{lcccccccl}
\hline & \multicolumn{1}{l}{ MPC distribution data } & & & & \\
\cline { 2 - 8 } MICs & 0.062 & 0.125 & 0.25 & 0.5 & 1 & 2 & $\mathrm{MPC}_{50}$ & $\mathrm{MPC}_{50}$ \\
\hline 0.016 & 17 & 5 & 1 & & & 0.062 & 0.125 \\
0.031 & & 9 & 17 & 5 & & 0.125 & 0.5 \\
$0.062-0.125$ & & 5 & 5 & 1 & & & 0.25 & 0.25 \\
0.25 & & & & & 2 & 1 & 1 & 2 \\
Total & 17 & 14 & 23 & 10 & 3 & 1 & 0.25 & 0.5 \\
\hline
\end{tabular}

MIC minimum inhibitory concentration, MPC mutant prevention concentrations, $M / C_{50}$ drug concentration at which $50 \%$ of strains are inhibited, $M I C_{90}$ drug concentration at which $90 \%$ of strains are inhibited, $M P C_{50}$ drug concentration at which $50 \%$ of strains are inhibited, $M P C_{90}$ drug concentration at which $90 \%$ of strains are inhibited. Concentrations are in $\mathrm{mg} / \mathrm{L}$

dose clarithromycin. For the strains with the MICs of $0.25 \mathrm{mg} / \mathrm{L}$ and $\mathrm{MPC}_{90}$ of $2 \mathrm{mg} / \mathrm{L}$, the MICs might increase to $2 \mathrm{mg} / \mathrm{L}$, since the subpopulations were able to survive in the concretions of $1 \mathrm{mg} / \mathrm{L}$.

When the dosage of clarithromycin is $500 \mathrm{mg}$ bid, the $\mathrm{T}_{\mathrm{MSW}}(\mathrm{h})$ is 0 for strains with the MICs of $0.016 \mathrm{mg} / \mathrm{L} ; 4$ for strains with the MICs of $0.031 \mathrm{mg} / \mathrm{L} ; 2$ for strains with the MICs ranging from 0.062 to $0.125 \mathrm{mg} / \mathrm{L}$; and 17 for strains with the MICs of $0.25 \mathrm{mg} / \mathrm{L}$. The $\mathrm{T}_{\mathrm{MSW}}$ values indicate that non-susceptible mutant subpopulations are less likely to be selectively enriched with the high-dose clarithromycin. However, for the strains with the MICs of $0.25 \mathrm{mg} / \mathrm{L}$, the $\mathrm{T}_{\mathrm{MSW}}$ is much higher, presenting a high risk for treatment failure.

\section{Discussion}

H. pylori, a major causative agent of chronic gastritis and peptic ulcers, is related to the pathogenesis of gastric mucosa-associated lymphoid tissue lymphomas and gastric adenocarcinomas [22, 23]. Stomach cancer is the second leading cause of cancer-related death in East Asia with China accounting for nearly $50 \%$ of all new stomach cancer cases diagnosed worldwide each year [6]. It is believed that eradication of $H$. pylori may prevent some of the complications associated with ulcer and gastric cancers [24]. Classical clarithromycin-containing triple therapy has been recognized as the firstline treatment for $H$. pylori infection, yet the effectiveness of this triple therapy has dropped from 88.54 to $71.13 \%$ in recent years. This decline in effectiveness has been attributed to the development of clarithromycin resistance in some $H$. pylori strains [7]. H. pylori resistance against clarithromycin is primarily attributed to point mutations in the variable region of the $23 S$ rRNA gene ( $\mathrm{V}$ region). The mutations result in a conformational change in the clarithromycin binding sites, resulting in lower binding and decreased drug sensitivity [25, 26]. Strains are considered to be resistant to clarithromycin when the MIC becomes $\geq 1 \mathrm{mg} / \mathrm{L}$ [27]. In this study, we discovered that the MICs increase with low-dose clarithromycin. For the strains with the MICs of $0.25 \mathrm{mg} / \mathrm{L}$ and $\mathrm{MPC}_{90}$ of $2 \mathrm{mg} / \mathrm{L}$, the non-susceptible mutant subpopulations were resistant to clarithromycin.

Two conditions are required for the phenotypic development of clarithromycin resistance in bacteria. The first condition is the emergence of drug-resistant mutant strains. Secondly, the drug-resistant mutant strains must be selectively enriched [14]. For $H$. pylori, the frequency of $23 S$ rRNA gene mutation is about $3 \times 10^{-9}$ and the bacterial load of $H$. pylori is between $10^{8}$ and $10^{11} \mathrm{CFU}$ in the stomach [28]. For this reason, clarithromycin-resistant mutants exist in almost all $H$. pylori-infected patients. The clarithromycin resistance mutants are not normally detected by standard susceptibility testing because it requires an inoculum size of $10^{6} \mathrm{CFU}$ [27]. Unlike many other bacteria, $H$. pylori cannot be

Table 3 Pharmacokinetic and pharmacodynamic (PKPD) values for clarithromycin

\begin{tabular}{|c|c|c|c|c|c|c|c|}
\hline \multirow[b]{2}{*}{ MICs } & \multicolumn{7}{|c|}{ Dosage $2 \times 200 \mathrm{mg} \mathrm{C}_{\max }{ }^{\mathrm{a}}=0.36 \mathrm{AUC}_{24}=4.20$} \\
\hline & $\mathrm{C}_{\max } / \mathrm{MIC}_{90}$ & $C_{\max } / M C_{90}$ & $\mathrm{AUC}_{24} / \mathrm{MIC}_{90}$ & $\mathrm{AUC}_{24} / \mathrm{MPC}_{90}$ & $\mathrm{~T}>\mathrm{MIC}_{90}$ & $\mathrm{~T}>\mathrm{MPC}_{90}$ & $\overline{T_{M S W}}$ \\
\hline 0.016 & 22.50 & 2.88 & 262.50 & 33.60 & 24 & $\sim 18$ & $\sim 6$ \\
\hline 0.031 & 11.61 & 0.72 & 135.48 & 8.40 & 24 & 0 & 24 \\
\hline $0.062-0.125$ & 5.81 & 1.44 & 67.74 & 16.80 & $\sim 20$ & $\sim 5$ & $\sim 15$ \\
\hline \multirow[t]{3}{*}{0.25} & 1.44 & 0.18 & 16.80 & 2.10 & $\sim 5$ & 0 & $\sim 5$ \\
\hline & \multicolumn{7}{|c|}{ Dosage $2 \times 500 \mathrm{mg} \mathrm{C}_{\max }{ }^{\mathrm{b}}=2.85 \mathrm{AUC}_{24}=41.72$} \\
\hline & $\mathrm{C}_{\max } / \mathrm{MIC}_{90}$ & $C_{\max } / M C_{90}$ & $\mathrm{AUC}_{24} / \mathrm{MIC}_{90}$ & $\mathrm{AUC}_{24} / \mathrm{MPC}_{90}$ & $\mathrm{~T}>\mathrm{MIC}_{90}$ & $\mathrm{~T}>\mathrm{MPC}_{90}$ & $\mathrm{~T}_{\mathrm{MSW}}$ \\
\hline 0.016 & 178.13 & 22.80 & 2607.50 & 333.76 & 24 & 24 & 0 \\
\hline 0.031 & 91.94 & 5.70 & 1345.81 & 83.44 & 24 & $\sim 20$ & $\sim 4$ \\
\hline $0.062-0.125$ & 45.97 & 11.40 & 672.90 & 166.88 & 24 & $\sim 22$ & $\sim 2$ \\
\hline 0.25 & 11.40 & 1.43 & 166.88 & 20.86 & $\sim 22$ & $\sim 5$ & $\sim 17$ \\
\hline
\end{tabular}

$C_{\max }$ serum maximum concentration, $A U C_{24}$ area under curve over a $24 \mathrm{~h}$ time period, $T_{M S W}$ time inside the mutant selection window (h). Concentrations are in mg/L

${ }^{a} C_{\max }$ was determined using a high-performance liquid chromatographic procedure and did not include 4-hydroxy-clarithromycin

${ }^{\mathrm{b}} \mathrm{C}_{\max }$ was determined using liquid chromatography tandem mass spectrometry and did not include 4-hydroxy-clarithromycin 
destroyed by the immune system, so that the drug-resistant mutant strains can be selectively enriched $[2,29]$. Previously, the frequency of clarithromycin resistance mutations was found to be $3 \times 10^{-9}$ for the UA802 strain, the MIC of which was $0.02 \mathrm{mg} / \mathrm{L} \mathrm{[18].} \mathrm{In} \mathrm{the} \mathrm{current}$ study, the frequency for clarithromycin-sensitive $H$. pylori to become resistant in one step was less than $10^{-10}$ for 65/68 (95.59\%) wild-type clinical isolates of H. pylori. Indeed, the MICs increased steadily. Before the MPC theory was proposed, researchers realized that the combination of two antibiotics was needed to achieve optimal cure rate $[5,6]$. Two drugs with separate bacterial targets can close the MSW if the pharmacokinetic parameters are optimized [15]. However, co-administration of clarithromycin with other drugs can only reduce the time in the MSW but not close it, since the pharmacokinetic parameters are not usually optimized. If scientists can optimize the dosage of clarithromycin to close the MSW, the eradication rate will likely increase and making it possible to avoid secondary resistance with less dosage.

We found that when clarithromycin was used in the treatment of respiratory infections, for the strains with the MICs of $0.031 \mathrm{mg} / \mathrm{L}$ and the $\mathrm{MPC}_{90}$ of $0.5 \mathrm{mg} / \mathrm{L}$, the clarithromycin concentrations were dropped in the MSW during the entire dosing interval. In other words, the MSW was opened the entire time. The non-susceptible mutant subpopulations were able to survive in the concertation of $0.25 \mathrm{mg} / \mathrm{L}$. When they were enriched to $10^{10} \mathrm{CFU}$, the new variants might present and be enriched again. For the strains with the MICs of 0.25 $\mathrm{mg} / \mathrm{L}$ and the $\mathrm{MPC}_{90}$ of $2 \mathrm{mg} / \mathrm{L}$, the $\mathrm{T}_{\mathrm{MSw}}$ was only $5 \mathrm{~h}$, while clarithromycin concentrations were under the $\mathrm{MPC}_{90}$ the entire time. It may need more time to enrich the variants, which can survive in the concertation of 1 $\mathrm{mg} / \mathrm{L}$. However, these will become clarithromycin-resistant strains. Before that, there might have been a mixture of stains with different MICs values.

When clarithromycin was used in the treatment of $H$. pylori infections, for most strains, the clarithromycin concentrations were above the MSW during the entire dosing interval. In other words, the MSW was closed the entire time. For the strains with the MICs of 0.25 $\mathrm{mg} / \mathrm{L}$ and the $\mathrm{MPC}_{90}$ of $2 \mathrm{mg} / \mathrm{L}$, the resistant mutants can easily be enriched in theory. While there were no significant differences between the eradication rate of them and that of other strains in this study. This may be due to the use of bismuth and amoxicillin, which may affect the enrichment of resistant mutants. Also, the number of the patients may have been too small to find the difference.

A history of prior clarithromycin use was considered to influence the failure rate of standard triple therapy in patients [13]. In this study, we found that the non-susceptible mutant variants might be enriched, resulting in a decrease in drug sensitivity. Despite most MPC values of the wild-type strains were under the MIC breakpoint of $1 \mathrm{mg} / \mathrm{L}$, the frequent low-dosage of the clarithromycin might steadily increase the MICs. When it reaches 0.25 $\mathrm{mg} / \mathrm{L}$, the variants of which will be able to survive in the concertation of $1 \mathrm{mg} / \mathrm{L}$. We can say that the MICs increase in every exposure to clarithromycin, unless all variants are killed. In return, it may be helpful to decrease the number of clarithromycin exposures and to avoid low-dosages when possible. If patients have used low-dosage clarithromycin several times in the past, clarithromycin should not be considered as the choice of the $H$. pylori treatment.

Despite MPC has many advantages over the MIC in theory, there are three limitations that may affect the clinical applications in the treatment of $H$. pylori infection. Firstly, the results of MPC and genotypic testing cannot reflect the actual characteristics of $H$. pylori in the whole stomach, even if the inoculum size reaches the bacterial load. For one thing, infection with both wild-type strains and variants of $H$. pylori strains is common during long-time chronic infection [30]. It is important to note that the MPC test theory is imperfect and has some level of inaccuracy. For example, the variants of $H$. pylori strains may have been lost in the recovery and subculture process, causing phenotypic susceptible strains revealed resistant genotype or genotypic resistant strains revealed susceptible phenotype, indicating that the result may not reflect all the variants of $H$. pylori strains in the stomach. Similar findings have been reported in the biopsies obtained from children and fecal specimens from young adults [31-33]. Secondly, the transformation of the $23 S$ rRNA gene may reduce the relevance of MPC values to clarithromycin resistance [34], since the spread of a clonal strain will reduce the importance of the emergence of new drug resistant strains [35]. Thirdly, the high bacteria load, the gastric $\mathrm{pH}$ level, the mucous layer, and the $H$. pylori intracellular life and colonization in niches with low antibiotic penetration can also affect the effectiveness of clarithromycin [36]. Additional in vivo and in vitro studies are needed to assess the application MSW theory in the treatment of $H$. pylori infection and the relationship between $\mathrm{AUC}_{24} / \mathrm{MPC}$ values and clarithromycin resistance.

\section{Conclusions}

In summary, this is the first study investigating the MSW of clarithromycin for clinical isolates of phenotypicallysensitive $H$. pylori. Low-dose clarithromycin may lead to decreased drug sensitivity or even clarithromycin resistance. Strains with a $0.25 \mathrm{mg} / \mathrm{L} \mathrm{MIC} \mathrm{display} \mathrm{a} \mathrm{high} \mathrm{risk} \mathrm{of}$ treatment failure. Additional in vivo and in vitro studies 
are needed to confirm the relationship between MPC values and clarithromycin resistance.

\section{Methods}

\section{Ethics statement}

The study was approved by Ethics Committee of Daping Hospital, Army Medical University, Chongqing, China (Ethics Approval Number: 20, 2017). All participants provided written informed consent prior to the study.

\section{Bacterial strains and antimicrobial agents}

A total of 68 clarithromycin-sensitive $H$. pylori clinical strains were used in this study. Two biopsy specimens from the antrum and the body were obtained during the endoscopic examination. They were mixed and then divided into two parts. One part was used for DNA extraction, while the other part was streaked onto an agar plate with selective medium containing polymyxin B, trimethoprim vancomycin, and nalidixic acid. All isolates were collected from Daping Hospital (Chongqing, China) and were susceptible to clarithromycin according to the recommended breakpoint of the Clinical \& Laboratory Standards Institute (CLSI) [9]. H. pylori isolates were placed in cryopreservation media and stored at $-70^{\circ} \mathrm{C}$. Mueller-Hinton II agar medium (Becton Dickinson, Sparks, MD, USA) was supplemented with 5\% defibrinated sheep blood without antibiotics. Clarithromycin (BioMerieux, St. Louis, MO, USA) was prepared according to the manufacturer's recommendations.

\section{Genotypic test}

Detection of clarithromycin resistance-associated mutations in the $23 S$ rRNA was conducted by polymerase chain reaction (PCR) and Sanger sequencing using $H$. pylori $23 S$ rRNA-specific primers as reported by Noguchi et al [37]. The sequence of the purified product was compared with the arrangement of the clarithromycin-sensitive $H$. pylori strain ACTC43504 using a Sequence Scanner (Thermo Fisher, Waltham, MA, USA).

\section{MIC determination}

The determination of MIC was performed according to CLSI guidelines and interpretations [27]. Isolates stored at $-70^{\circ} \mathrm{C}$ were thawed and subcultured using MuellerHinton (MH) II agar medium supplemented with 5\% defibrinated sheep blood. Isolated colonies were suspended in phosphate-buffered saline (PBS) and adjusted to a concentration of $1 \times 10^{8} \mathrm{CFU} / \mathrm{mL}$. Next, $10 \mu \mathrm{L}$ of the bacterial suspension containing $1 \times 10^{6} \mathrm{CFU}$ of bacteria was added to each $\mathrm{MH}$ agar plates containing $5 \%$ defibered sheep blood and various concentrations of clarithromycin. Concentrations of clarithromycin were tested by doubling the dilutions from 0.016 to $0.5 \mathrm{mg} / \mathrm{L}$.
The plate was incubated at $37^{\circ} \mathrm{C}$ under microaerophilic conditions $\left(10 \% \mathrm{O}_{2}, 5 \% \mathrm{CO}_{2}\right.$, and $\left.85 \% \mathrm{~N}_{2}\right)$ for $72 \mathrm{~h}$. The MIC was defined as the lowest drug concentration that prevented the visible growth of $H$. pylori isolates. $H$. pylori ACTC43504 was used as the standard for each set of MIC measurements.

\section{MPC determination}

The determination of MPC was performed according to a method reported by Zhang et al. [38]. Briefly, $H$. pylori were cultured in brain heart infusion (BHI) broth containing $5 \%$ fetal bovine serum and incubated for $72 \mathrm{~h}$. Cultures were centrifuged at $5000 \times g$ for 10 min, suspended in PBS, and adjusted to a concentration of $1 \times 10^{11} \mathrm{CFU} / \mathrm{mL}$. Next, $100 \mu \mathrm{L}$ of the bacterial suspension containing $1 \times 10^{10} \mathrm{CFU}$ of bacteria was added to each $\mathrm{MH}$ agar plates containing $5 \%$ defibered sheep blood and various concentrations of clarithromycin. Concentrations of clarithromycin were tested by doubling the dilutions from 1 to 64-times the MIC. The plate was incubated at $37^{\circ} \mathrm{C}$ under microaerophilic conditions $\left(10 \% \mathrm{O}_{2}, 5 \% \mathrm{CO}_{2}\right.$, and $85 \% \mathrm{~N}_{2}$ ) for $72 \mathrm{~h}$. The MPC was defined as the lowest concentration of drug that prevented the visible growth of $H$. pylori isolates.

\section{Statistical analysis}

The univariate analysis was performed by using KruskalWallis $\mathrm{H}$ Test. The analysis of the relation between MICs and MPCs was performed using Spearman rank correlation coefficient. A $P$-value of $\leq 0.05$ was considered significant.

\section{Abbreviations}

MIC: Minimum inhibitory concentration; MPC: Mutant prevention concentration; MSW: Mutant selection window; PCR: Polymerase chain reaction; PKPD: Pharmacokinetic and pharmacodynamics

\section{Acknowledgements}

Not applicable.

\section{Authors' contributions}

ZHF and CHL designed the study. LF, JY, XYH and YZ collected and analyzed the data. JY, LF and YG contributed samples collection and intellectual input. ZHF and CHL drafted and wrote the manuscript. LF, YG and YZ revised the manuscript critically for intellectual content. All authors gave intellectual input to the study and approved the final version of the manuscript.

\section{Funding}

This work is supported by the National Natural Science Foundation (No. 81472006) and the Undergraduate Innovation and Entrepreneurship Training Program (No. 201790031048). The authors declare that they have no financial relationship with the organization that sponsored the research, and the funding body was not involved in study design, data collection, analysis and writing of the study.

\section{Availability of data and materials}

All data generated or analyzed during this study are included within the article. 


\section{Ethics approval and consent to participate}

The study was approved by Ethics Committee of Daping Hospital, Army Medical University, Chongqing, China (Ethics Approval Number: 20, 2017). All procedures performed in studies involving human participants were in accordance with the ethical standards of the institutional and national research committee and with the 1964 Helsinki declaration and its later amendments or comparable ethical standards. Written informed consent was obtained from all individual participants included in the study.

\section{Consent for publication}

All data published here are under the consent for publication.

\section{Competing interests}

The authors declare that they have no competing interests.

\section{Author details}

'College of Basic Medical Sciences, Army Medical University, Chongqing 400042, China. ${ }^{2}$ Department of Gastroenterology, Daping Hospital, Army Medical University, 10 Changjiang Branch Road, Chongqing 400042, China.

Received: 3 January 2019 Accepted: 29 July 2019

Published online: 05 August 2019

\section{References}

1. Abadi ATB. Resistance to clarithromycin and gastroenterologist's persistence roles in nomination for helicobacter pylori as high priority pathogen by World Health Organization. World J Gastroenterol. 2017;23:6379-84.

2. Sobala GM, Crabtree JE, Dixon MF, Schorah CJ, Taylor JD, Rathbone BJ, et al. Acute helicobacter pylori infection: clinical features, local and systemic immune response, gastric mucosal histology, and gastric juice ascorbic acid concentrations. Gut. 1991;32:1415-8.

3. Peterson WL, Graham DY, Marshall B, Blaser MJ, Genta RM, Klein PD, et al. Clarithromycin as monotherapy for eradication of helicobacter pylori: a randomized, double-blind trial. Am J Gastroenterol. 1993;88:1860-4.

4. Graham DY, Opekun AR, Klein PD. Clarithromycin for the eradication of helicobacter pylori. J Clin Gastroenterol. 1993;16:292-4.

5. al-Assi MT, Genta RM, Karttunen TJ, Graham DY. Clarithromycin-amoxycillin therapy for helicobacter pylori infection. Aliment Pharmacol Ther. 1994;8:453-6.

6. Logan RP, Gummett PA, Schaufelberger HD, Greaves RR, Mendelson GM, Walker MM, et al. Eradication of helicobacter pylori with clarithromycin and omeprazole. Gut. 1994:35:323-6.

7. Malfertheiner P, Megraud F, O'Morain CA, Gisbert JP, Kuipers EJ, Axon AT, et al. Management of Helicobacter pylori infection-the Maastricht V/Florence consensus report. Gut. 2017;66:6-30.

8. Malfertheiner P, Megraud F, O'Morain CA, Atherton J, Axon AT, Bazzoli F, et al. Management of Helicobacter pylori infection--the Maastricht IV/ Florence consensus report. Gut. 2012;61:646-64.

9. Asaka M, Kato M, Takahashi S, Fukuda Y, Sugiyama T, Ota H, et al. Guidelines for the management of helicobacter pylori infection in Japan: 2009 revised edition. Helicobacter. 2010;15:1-20.

10. Fock KM, Katelaris P, Sugano K, Ang TL, Hunt R, Talley NJ, et al. Second AsiaPacific consensus guidelines for helicobacter pylori infection. J Gastroenterol Hepatol. 2009;24:1587-600

11. Hunt RH, Xiao SD, Megraud F, Leon-Barua R, Bazzoli F, van der Merwe S, et al. Helicobacter pylori in developing countries. World gastroenterology organisation global guideline. J Gastrointestin Liver Dis. 2011;20:299-304.

12. Global priority list of antibiotic-resistant bacteria to guide research, discovery, and development of new antibiotics. https://doi.org/10.4103/jms.jms_25_17.

13. Lim SG, Park RW, Shin SJ, Yoon D, Kang JK, Hwang JC, et al. The relationship between the failure to eradicate helicobacter pylori and previous antibiotics use. Dig Liver Dis. 2016;48:385-90.

14. Zhao X, Drlica K. Restricting the selection of antibiotic-resistant mutants: a general strategy derived from fluoroquinolone studies. Clin Infect Dis. 2001;33(Suppl 3):S147-56.

15. Epstein BJ, Gums JG, Drlica K. The changing face of antibiotic prescribing: the mutant selection window. Ann Pharmacother. 2004:38:1675-82.

16. Blondeau JM, Borsos S, Blondeau LD, Blondeau BJ, Hesje CE. Comparative minimum inhibitory and mutant prevention drug concentrations of enrofloxacin, ceftiofur, florfenicol, tilmicosin and tulathromycin against bovine clinical isolates of Mannheimia haemolytica. Vet Microbiol. 2012;160:85-90
17. Linde HJ, Lehn N. Mutant prevention concentration of nalidixic acid, ciprofloxacin, clinafloxacin, levofloxacin, norfloxacin, ofloxacin, sparfloxacin or trovafloxacin for Escherichia coli under different growth conditions. J Antimicrob Chemother. 2004:53:252-7.

18. Metzler K, Hansen GM, Hedlin P, Harding E, Drlica K, Blondeau JM. Comparison of minimal inhibitory and mutant prevention drug concentrations of 4 fluoroquinolones against clinical isolates of methicillinsusceptible and -resistant Staphylococcus aureus. Int J Antimicrob Agents. 2004:24:161-7.

19. Kehrenberg C, de Jong A, Friederichs S, Cloeckaert A, Schwarz S. Molecular mechanisms of decreased susceptibility to fluoroquinolones in avian Salmonella serovars and their mutants selected during the determination of mutant prevention concentrations. J Antimicrob Chemother. 2007:59:886-92.

20. Hansen GT, Zhao X, Drlica K, Blondeau JM. Mutant prevention concentration for ciprofloxacin and levofloxacin with Pseudomonas aeruginosa. Int J Antimicrob Agents. 2006;27:120-4.

21. Metzler K, Drlica K, Blondeau JM. Minimal inhibitory and mutant prevention concentrations of azithromycin, clarithromycin and erythromycin for clinical isolates of Streptococcus pneumoniae. J Antimicrob Chemother. 2013;68:631-5.

22. Dooley CP, Cohen H, Fitzgibbons PL, Bauer M, Appleman MD, Perez-Perez $\mathrm{Gl}$, et al. Prevalence of helicobacter pylori infection and histologic gastritis in asymptomatic persons. N Engl J Med. 1989:321:1562-6.

23. Wang DZ, Chen W, Yang S, Wang J, Li Q, Fu Q, et al. Helicobacter pylori infection in Chinese patients with atrial fibrillation. Clin Interv Aging. 2015; 10:813-9.

24. Graham DY, Lee YC, Wu MS. Rational helicobacter pylori therapy: evidencebased medicine rather than medicine-based evidence. Clin Gastroenterol Hepatol. 2014;12:177-86 e3 Discussion e12-3.

25. Wang G, Taylor DE. Site-specific mutations in the $23 \mathrm{~S}$ rRNA gene of helicobacter pylori confer two types of resistance to macrolide-lincosamidestreptogramin B antibiotics. Antimicrob Agents Chemother. 1998:42:1952-8.

26. Shen J, Zhang JZ, Ke Y, Deng D. Formation of A2143G mutation of $23 \mathrm{~S}$ rRNA in progression of clarithromycin resistance in helicobacter pylori 26695. Microb Drug Resist. 2005;11:100-6.

27. CLSI. Methods for antimicrobial dilution and disk susceptibility testing of infrequently isolated or fastidious bacteria, 3rd edition. CLSI document M45. Wayne, PA: Clinical and Laboratory Standards Institute; 2015.

28. Khulusi S, Mendall MA, Patel P, Levy J, Badve S, Northfield TC. Helicobacter pylori infection density and gastric inflammation in duodenal ulcer and non-ulcer subjects. Gut. 1995;37:319-24.

29. Wang J, Brooks EG, Bamford KB, Denning TL, Pappo J, Ernst PB. Negative selection of $\mathrm{T}$ cells by helicobacter pylori as a model for bacterial strain selection by immune evasion. J Immunol. 2001;167:926-34.

30. Alebouyeh M, Yadegar A, Farzi N, Miri M, Zojaji H, Gharibi S, et al. Impacts of H. pylori mixed-infection and heteroresistance on clinical outcomes. Gastroenterol Hepatol Bed Bench. 2015;8:S1-5.

31. Aguilera-Correa JJ, Urruzuno P, Barrio J, Martinez MJ, Agudo S, Somodevilla $A$, et al. Detection of helicobacter pylori and the genotypes of resistance to clarithromycin and the heterogeneous genotype to this antibiotic in biopsies obtained from symptomatic children. Diagn Microbiol Infect Dis. 2017:87:150-3.

32. Osaki T, Mabe $\mathrm{K}$, Zaman $\mathrm{C}$, Yonezawa $\mathrm{H}$, Okuda M, Amagai $\mathrm{K}$, et al. Usefulness of detection of clarithromycin-resistant helicobacter pylori from fecal specimens for young adults treated with eradication therapy. Helicobacter. 2017;22.

33. De Francesco V, Zullo A, lerardi E, Giorgio F, Perna F, Hassan C, et al. Phenotypic and genotypic helicobacter pylori clarithromycin resistance and therapeutic outcome: benefits and limits. J Antimicrob Chemother. 2010;65:327-32.

34. Taylor DE, Ge Z, Purych D, Lo T, Hiratsuka K. Cloning and sequence analysis of two copies of a $23 \mathrm{~S}$ rRNA gene from helicobacter pylori and association of clarithromycin resistance with $23 \mathrm{~S}$ rRNA mutations. Antimicrob Agents Chemother. 1997:41:2621-8.

35. Smith HJ, Walters M, Hisanaga T, Zhanel GG, Hoban DJ. Mutant prevention concentrations for single-step fluoroquinolone-resistant mutants of wildtype, efflux-positive, or ParC or GyrA mutation-containing Streptococcus pneumoniae isolates. Antimicrob Agents Chemother. 2004;48:3954-8.

36. Papastergiou V, Georgopoulos SD, Karatapanis S. Treatment of helicobacter pylori infection: past, present and future. World J Gastrointest Pathophysiol. 2014;5:392-9. 
37. Noguchi N, Rimbara E, Kato A, Tanaka A, Tokunaga K, Kawai T, et al. Detection of mixed clarithromycin-resistant and -susceptible helicobacter pylori using nested PCR and direct sequencing of DNA extracted from faeces. J Med Microbiol. 2007;56:1174-80.

38. Zhang $X$, Jiang A, Yu H, Xiong Y, Zhou G, Qin M, et al. Human lysozyme synergistically enhances bactericidal dynamics and lowers the resistant mutant prevention concentration for metronidazole to helicobacter pylori by increasing cell permeability. Molecules. 2016;21.

\section{Publisher's Note}

Springer Nature remains neutral with regard to jurisdictional claims in published maps and institutional affiliations.

Ready to submit your research? Choose BMC and benefit from:

- fast, convenient online submission

- thorough peer review by experienced researchers in your field

- rapid publication on acceptance

- support for research data, including large and complex data types

- gold Open Access which fosters wider collaboration and increased citations

- maximum visibility for your research: over $100 \mathrm{M}$ website views per year

At $\mathrm{BMC}$, research is always in progress.

Learn more biomedcentral.com/submissions 